Füzi Izabella

\title{
Az oktatási kihívások pszichológiai vonatkozásai Interjú Szabó Évával
}

\author{
Szerzó \\ Szabó Éva pszichológus. 1986-tól öt éven át iskolapszichológusként dolgozott, ezt követôen került \\ a felsôoktatásba, ahol elsôsorban szociálpszichológiát és iskolapszichológiát tanít. 2009 óta a Dél- \\ alföldi Iskolapszichológiai Módszertani Központ vezetôje, és az országos iskolapszichológus \\ hálózat egyik meghatározó alakja. Kutatási területei az iskolai élettel összefüggó problémák \\ megértése köré szerveződnek. Számos tanári konferencián és továbbképzésen meghívott \\ elöadóként igyekszik felfrissíteni a pedagógusok pszichológiai tudását, ahogy a 2017-ben \\ megjelent Pedagógusok Pszichológiai Kézikönyvével is ez volt a célja, amelynek egyik szerkesztóje \\ volt. Több alkalommal vett részt elöadóként a digitális generációval kapcsolatos problémák \\ megértésével és megoldásával foglalkozó pedagógiai konferenciákon, továbbképzéseken. \\ Elkötelezett azokban a kutatásokban, amelyek célja a pedagógiai kultúra fejlesztése, az iskolai \\ eredményesség pszichológiai hátterének megértése és az eredmények gyakorlati hasznosítása.
}

https://doi.org/10.31176/apertura.2018.2.2 


\section{Füzi Izabella}

\section{Az oktatási kihívások pszichológiai vonatkozásai Interjú Szabó Évával}

Füzi Izabella: Ön szerint melyek azok a legnagyobb kihívások, melyekkel a 21. században az oktatásnak, különös tekintettel a felsóoktatásra, szembe kell néznie?

Szabó Éva: Több kritikus pont van. Az egyik legfontosabb a digitális fejlődés által kiváltott idegrendszeri változások, figyelmi kapacitásbeli jellemzók és információfeldolgozási sajátosságok változása. Ennek a témának mára már széles szakirodalma van, amely azonban elsôsorban a közoktatásra fókuszál, tekintve, hogy a digitális generáció problémái még csak most kezdenek elérni a felsôoktatás szintjére. Azonban pár éven belül kimennek a felsôoktatásból azok a diákok, akik még a papír-ceruza alapú világban szocializálódtak, és fokozatosan feltöltik a helyüket a tableteken, okostelefonokon és hypertexten nevelkedettek. Számukra a hagyományos oktatási forma, amit nálunk szemléletesen még a diákság megnevezése - a „hallgató” is - szimbolizál nem lesz kellóen figyelemfelkeltő és motiváló. Nehezen tudnak hosszasan élóbeszédre figyelni, a lineáris információfeldolgozás helyett a horizontális kerül elôtérbe, a tisztán verbális helyét a képi információéhség veszi át. Ezen felül igénylik a folyamatos aktivitást, de lényegesen alacsonyabb a monotóniatû́résük, mint a korábbi generációknak.

A gyors információáramláshoz és felgyorsult életritmushoz képest az egyetem lassúnak és unalmasnak tûnhet. Az információk kihámozása hosszabb szövegekból hypertext kiemeléses segítség nélkül rendkívül fáradtságosnak látszik, és szintén időigényes. A korszak másik legfóbb jellemzôje a félkész-kész termék szemlélet. Ez az ún. gyorsétterem-szemlélet nemcsak a hétköznapi viselkedésben, de az információszerzésben is elôtérbe kerül. Keresik az elöre feldolgozott, kivonatolt, mások által elókészített anyagokat, mint pl. a tanárok prezentációi vagy az interneten található különbözô „segédanyagok”. Nem szívesen olvasnak és dolgoznak fel eredeti, nyers szövegeket, fárasztónak találják az olyan gondolkodási múveleteket, mint az összehasonlítás, kritikai elemzés, stb. Ezeket a hétköznapokban is keresőmotorok segítik. Összevetik a szállodák árait, a termékek tesztjeit stb., hogy nekünk ezzel ne kelljen foglalkozni, csak a végeredményt nézzük meg: melyik a legolcsóbb, melyik a legjobb. A tanulás, különösen a bölcsész- és társadalomtudományi típusú tárgyak esetében, ehhez a rendszerhez nehezen fog alkalmazkodni, mert jellegében meglehetôsen távol áll ettól.

FI: Hogyan ragadható meg az „idegrendszeri” és az „információfeldolgozási sajátosságok” megváltozásának a kérdése pszichológiai összefüggésekben? A médiatörténet perspektívája felól azt is mondhatnánk, hogy ami ma történik, nem feltétlenül példátlan, drámai változás, hanem besorolható a médiumváltások történetébe, tekintve, hogy az írás megjelenése, a könyvnyomtatás elterjedése, a technikai rögzítô médiumok (fotográfia, mozgókép, 
hangrögzítés) használata már korábban is befolyásolta az észlelés, a tanulás, a képzelet, az emlékezet folyamatait. Pszichológiai értelemben hogyan pontosíthatnánk a digitális váltásnak az emberi pszichére tett kihatásait, mint ami az evolúciósan rögzített érzékelési-észlelési rendszer múködését is megváltoztatja, vagy csak a magasabb rendú feldolgozási sémákra van hatással?

SZÉ: A változás alapvetôen az információfeldolgozási sémákkal, információpreferenciákkal kapcsolatban érhetố tetten, de nyilvánvalóan megjelenik a feldolgozásban szerepet játszó agyi struktúrák változásában is. Az agyi plaszticitás elmélete rámutat, hogy azok az idegrendszeri területek, amelyeket gyakrabban ingerelünk, úgymond többet használunk, gyorsabban fejlődnek, intenzívebben kezdenek múködni, míg mások, amiket háttérbe szorítunk, kissé csökkennek kiterjedésben is, de aktivitásban egyértelmúen. A vizualitás irányába erôsen eltolódott információfeldolgozási követelmény nyilván kiváltja ezeknek a területeknek a fokozott aktivitását. A lineárisan haladó olvasás, a korábbi könyvek lapozgatását is magában foglaló információszerzés összetettebb idegrendszeri izgalommal járt. Pl. a lapok érintése, a könyv súlya, a nyomdafesték és a papír illata kiegészítette a sûrún teleírt oldalak vizuális ingerlô hatását. A gyorsan változó, elsôsorban képekre, háromdimenziós ábrázolásra orientált információfelvétel során ezek nem jelennek meg. Hasonlóan befolyásolja az agy múködését a kézírás fokozatos háttérbe szorulása. Az írás, ábrarajzolás mind hozzájárult az információ rögzítéséhez. Ezeknek a mozgásoknak az agy felé közvetített bonyolult ingereit nem helyettesíti az egér vagy a billentyúzet használata.

FI: Mennyiben viseli magán a jelenlegi oktatási intézményrendszerünk egy sajátos történeti korszak (például az indusztriális társadalom) eszmerendszerét, világképét, emberfogalmát? Mennyire gyorsan és rugalmasan reagál az oktatási rendszer a társadalmi, politikai, gazdasági változásokra? Kell-e ezekhez egyáltalán alkalmazkodnia?

SZÉ: Az oktatási rendszer erôteljes lemaradásban van a társadalmi változások kihívásaihoz képest. A jelenlegi társadalom fogyasztói szemlélete és „szupermost” jellege erôteljesen megjelenik a gyerekek viselkedésében és igényeiben. Az oktatás ehhez képest a jól bevált XX. századi módszerekbe kapaszkodik, eltekintve a még mindig alternatívnak vagy újítónak számító kezdeményezésektôl. Sem a tankönyvek szellemisége, sem a tanárok módszertani felkészültsége és sok esetben az iskolák felszereltsége sem tud megfelelni a modern kihívásoknak.

Hogy meg kell-e felelni, az többrétegú kérdés. Módszertani szempontból valószínúleg igen, ha szeretnénk, hogy az általunk fontosnak vélt tartalmak eljussanak a diákokhoz. Azonban az már sokkal problematikusabb kérdés, hogy mennyire kell az iskolának átvennie ezt a szupermost, gyorséttermi szemléletet, mennyire kell megmaradnia annak a helynek, ahol az egymásra figyelés, az együttmúködés és a tiszteletre épülô együttélés szabályait tanulják a gyerekek. Ezen túlmenôen a kritikai gondolkodást, az elmélyült elemzést, az olykor unalmasnak túnő feladatok megoldására való képességet, a kitartást és a késleltetést is gyakorolják. 
FI: Hogyan változtatja meg az oktatás tartalmát, feladatát a technológiai elôrehaladás? Az élet minden területét átfogó, növekvô automatizáció felértékeli-e esetleg a csak az emberre jellemzó problémamegoldási képességet? Hogyan lehet ezt módszertani összefüggésekre lefordítani?

SZÉ: A XX. század második harmadáig, az oktatás feladata az információk átadása volt. A tudás elsődleges forrása a pedagógus és a tankönyv volt. A tanárok jelentôs információmennyiséget halmoztak fel, és ezt rendszerezetten megpróbálták átadni tanítványaiknak. A technikai fejlôdésnek, elsôsorban a digitális információs forradalomnak köszönhetôen a pedagógusok elvesztették ezt a korábban privilegizált szerepüket. Egy jó keresố motor pár másodperc alatt választ ad szinte bármely kérdésre, vagy könnyedén elvezet minket a kívánt információ forrásához, onnan további elágazásokkal eljuthatunk további, az elsô elemmel összefüggó információkhoz, és a láncnak szinte nincs vége. A neten való tájékozódás gyors és hatékony lehetôség a mai diákok számára, a tények fellelésének közvetlen és adott esetben kifejezetten szórakoztató módja. Ugyanakkor az elérhetô információk egy része pontatlan, más részük valaki által szerkesztett vagy interpretált formában kerül elô, ami tartalmazhat tévedéseket, félreértelmezéseket, szándékosan vagy „ártatlanul” félrevezetve ezáltal az olvasót. Ezért a tanárok szerepe ebben a digitális és technológiával felszerelt világban már nem elsôsorban a tudás átadása, sokkal inkább az információ keresésének, rendszerezésének, értelmezésének tanítása. A kritikai gondolkodás, a több forrásból származó információ összevetése, feldolgozása, a kapott információk kombinálása, a problémamegoldási készség fejlesztése lenne a legfontosabb feladat. Másrészt a korábbi tanulási környezet kifejezetten az egyéni gyakorlást, a magányos tanulást igényelte. A tények megjegyzése és visszaidézése leginkább akkor sikeres, ha egyedül vagyunk, nem vonja el a figyelmünket semmi. Azonban a problémamegoldás a jelenségek többoldalú elemzését, megértését és egymástól eltérô kompetenciák együttes használatát feltételezi. Az együttmúködés, a csapatban való dolgozás, a másoktól tanulás, mind olyan kihívások, amelyeknek a jelenlegi iskolai oktatás még nem tud megfelelni. Pedig a technikai vívmányok, közöttük is a megosztással végezhetô közös tevékenységeket lehetôvé tevő eszközök használata (akárcsak egy egyszerú Google-dokumentum közös szerkesztése), pontosan a másokkal való együttmúködést, a feladat megszervezését igényli és támogatja. A technika új platformot teremt a közös munkának. Virtuális kommunikációs lehetôségeket, amelyek lehetôvé teszik az egymástól térben, ill. akár idôben is elszakadó, mégis közös tevékenységet. Mindez azt jelenti, hogy a XXI. századi pedagógiának egyre nagyobb mértékben kell támaszkodnia az IKT-eszközök használatára. De nem abban az értelemben, hogy a tanár varázslatos trükköket mutasson be a digitális táblán. Sokkal inkább abba az irányba kéne elmozdulni, hogy a gyerekek tanulási folyamatát ennek segítségével tervezze meg. Az információszerzés áttevődhet az iskolán kívüli idôszakra, az iskolában töltött idô ennek rendszerzésével, alkalmazásával kéne hogy teljen, természetesen a pedagógus vezetésével, irányításával. Ami a legfontosabb, hogy a pedagógusok szerepe egyáltalán nem szorul háttérbe, sốt bizonyos szempontból fontosabb, mint valaha, de jelentôsen át kell hogy alakuljon.

FI: Az információkhoz való gyors és látszólag akadálytalan hozzáférés hogyan változtatja meg a tudás státuszát, és milyen terheket ró az emberi pszichére? Egy olyan világban, ahol a 
legalapvetóbb hétköznapi jelenségekhez (mint például a helyes táplálkozás vagy az egészséges életmód) eltérố tudományos álláspontok, egymással ellentétes trendek kapcsolódnak, mik lehetnek az egyéni stratégiák az információ- és véleményözönben való eligazodásban, és milyen segítséget nyújthat ebben az oktatás?

SZÉ: A tudás mint ismeretekre való emlékezés valóban értékét veszti. Azonban ennek a rendkívül sokrétú infokommunikációs eszközrendszernek a használata mint tudás hihetetlenül felértékelódik. Ki találja meg leggyorsabban, legkevesebb téves oldalmegnyitásból, legpontosabban a választ bizonyos kérdésekre, ez látszik ma nagy értéknek. De azért az a fajta tudás, hogy mit is kéne megkeresni, mi mivel hogyan függ össze, mely kérdések vezetnek el helyes válaszokhoz, mégis egy olyan érték, ami csak az emberi agyban jöhet létre. A pedagógusok szerepe itt felbecsülhetetlen. Ôk ismerik a tudást, amihez a diákokat is hozzá akarják juttatni, tehát ismerik a célt. Abban kell tehát segíteniük, hogy a diákok jó kérdéseket tudjanak megfogalmazni, és a lehetséges sokféle, akár egymásnak ellentmondó válaszok közül megfelelô mérlegelés, hipotézistesztelés útján megtalálják a legoptimálisabb választ.

Az interneten felhalmozott információk egy része valóban nem értékes, téves vagy egyszerúen elavult. A pedagógusok feladata lehet, hogy megértessék ezt a diákokkal. Tanítsák meg ôket arra, hogy nem kell mindent elhinni, amit valaki megoszt, vagy leír. Hogy lássák a különbséget különböző források között. Képesek legyen tesztelni a kapott információt. A legfontosabb, hogy felkeltsék bennük ezt az igényt. Hogy a diákok akarják tudni, hogy amit olvasnak, az mennyire valós, mennyi bizonyíték támasztja alá, hogy hiteles-e a forrás, amelyből származik. Ez nagy kihívás, és igazán pedagógushoz méltó feladat.

FI: Hogyan befolyásolja a publikus és privát szféra lassan totálissá váló mediatizáltsága az oktatás feladatait? Hogyan látja a médiaoktatás szerepét és helyét a közoktatásban? 
SZÉ: A digitális világban való létezés bizonyos szempontból ugyanolyan, mint a valós kapcsolatokban, másrészt vannak különbségek. Például a megosztott információ, az élôszóban egy embernek elmondott pletykához képest, sokkal nagyobb körben és lényegesen gyorsabban terjed. Mindenki, aki rajta van valamilyen közösségi médiaalkalmazáson vagy -eszközön, lényegében a tömegkommunikáció szabályai szerint múködik. Amit írunk, kiteszünk, egyszerre sok emberhez eljut, akik közül sokan passzív befogadói lesznek, néhányan interaktívan reagálhatnak is. Így a kijelentések feleloossége sokkal nagyobb, mintha azt négyszemközt mondjuk ki élooszóban. Különösen igaz ez a sértô, hazug vagy rosszindulatú állítások ártó hatására. A médiaoktatás egyik legfontosabb feladata ezért a digitális felelôsség megértetése, hogy felhívja a figyelmet arra, hogy a média egy hatalmi eszköz, amellyel visszaélni veszélyes. Nem az elrettentés, sokkal inkább azetikai érzékenység fejlesztése lenne a cél. És nemcsak mások vonatkozásában, de önmagukvédelme érdekében is. Másrészt a médiaforrások kritikai elemzése lenne az oktatás feladata, hogya diákok rászokjanak az egészséges médiaszkepszisre. Legalább tegyék fel a kérdést, hogy amitlátnak, olvasnak, az valóságos vagy kreált, illetve annak megtanítása, hogy miként tudják eztellenôrizni, értékelni.

\section{FI: Hogyan változott az utóbbi években a tanulás és a tanítás természetéról vallott felfogás, és ennek milyen konkrét hatásai lehetnek a tanteremben?}

SZÉ: Amennyire én látom, a változás egyelôre inkább elméleti. Szakcikkek ezrei jelennek meg a digitálisnak nevezett generáció eltérô információfeldolgozási módjairól és arról, miként kellene ehhez viszonyulni a pedagógusoknak. Ezzel párhuzamosan azonban a tanárképzés olyan intézményekben zajlik, amelyek közül sokban az elemi IKT-s feltételek sincsenek meg a tantermekben, ahol az oktatók jelentôs része nem használ ilyen eszközöket, és nem is tudja megmutatni, miként kéne máshogyan tanítani. A tanárok továbbképzése néhány nagyszerú kezdeményezéstôl eltekintve szintén inkább csak a problémáról szól, nem a megoldásokról. Egy paradox helyzetet látok, amelyben a leggyorsabban változó generációt a leglassabban reagáló rendszerben próbáljuk tanítani.

FI: A fentiek alapján mondhatjuk-e azt, hogy az oktatásnak a jelenlegi média- és társadalmi környezetben kettôs feladata van: egyrészt alkalmazkodjon az újmédiás információfeldolgozási sémákhoz, másrészt kompenzálja azokat a készségeket, képességeket és tudástípusokat, melyek ebben az új környezetben nem jelennek meg? A nevelésnek ez a két koncepciója (hatékony információátadás és formálás, alakítás) mennyiben egyeztethetô össze a tanórán?

SZÉ: Igen, egyetértek abban, hogy ezt a komplex feladatot kellene megvalósítani. Az, hogy ez tanórai hagyományos keretek között mennyire megvalósítható, már igényel némi tanári leleményességet. Vannak feladatok, amelyeket jobb volna projekthét keretében megoldani, az információelemzés, kritikai feldolgozás teljesen megvalósítható órai keretben is, ha rendelkezésre áll wifi, kivetítő, okostábla. Hasznos, ha a diákok a saját eszközeiket használhatják erre a célra. Pl. mindenki keressen rá egy kulcsszóra, hasonlítsák össze a találataikat, és ezt követően lehet beszélni az irányító keresômotorok hatalmáról. Rá lehet mutatni a szelektív információ felbukkanásra pl. el 
lehet magyarázni, hogy egyáltalán miként múködnek a különbözô keresôk. Hogyan befolyásolja az egyik keresés a következôt stb. Ez persze csak egy példa, amellyel csupán a szemléletet szerettem volna illusztrálni. Az ilyen órákat nem lehet percre elöre tervezni. A tanárnak fontosabb, hogy ismerje a célokat, amiket meg akar valósítani, mint a módszert vagy a sorrendet, ahogy ezt el is éri. Ahogy a digitalizált világban csökkent a kiszámíthatóság, túl gyorsak a változások, úgy értékelődik fel a rugalmasság és a belsô tájékozódási pontok szerepe. A jövő pedagógusainak is ezeket az erényeket kell majd fejleszteni. Biztos tudástámpontokkal és nagyon rugalmas módszertani hozzáállással kell rendelkezniük ahhoz, hogy sikeresek legyenek. 
(C) Apertúra, 2018. tél | www.apertura.hu

webcím: https://www.apertura.hu/2018/tel/fuzi-az-oktatasi-kihivasok-pszichologiai-vonatkozasaiinterju-szabo-evaval/

https://doi.org/10.31176/apertura.2018.2.2

\section{Apertura.hu}

Image not found or type unknown 